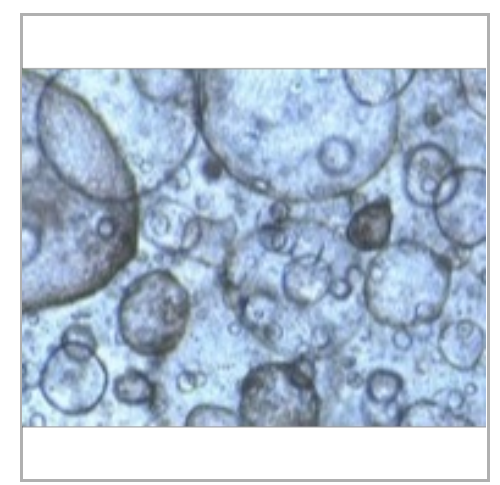

JUL 07, 2020

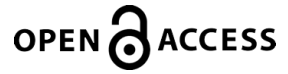

DOI:

dx.doi.org/10.17504/protocol s.io.bfvnjn5e

Protocol Citation: Hazel Rogers, Laura Letchford, Sara Vieira, Maria Garcia-Casado, Mya Fekry-Troll, Charlotte Beaver, Rachel Nelson, Hayley Francies, Mathew Garnett 2020. Derivation of organoids from primary tumour tissue. protocols.io https://dx.doi.org/10.17504/p rotocols. io. bfvnjn5e

License: This is an open access protocol distributed under the terms of the Creative Commons Attribution License, which permits unrestricted use, distribution, and reproduction in any medium, provided the original author and source are credited

Protocol status: Working We use this protocol and it's working

Created: May 01, 2020

Last Modified: Jul 07, 2020

PROTOCOL integer ID: 36494

\section{(3) Derivation of organoids from primary tumour tissue}

$\rightarrow$ In 1 collection

\author{
Hazel Rogers ${ }^{1}$, Laura Letchford ${ }^{1}$, Sara Vieira ${ }^{1}$,
} Maria Garcia-Casado ${ }^{1}$, Mya Fekry-Troll ${ }^{1}$, Charlotte Beaver ${ }^{1}$, Rachel Nelson ${ }^{1}$, Hayley Francies ${ }^{1}$, Mathew Garnett ${ }^{1}$

${ }^{1}$ Wellcome Sanger Institute

\section{Cellular Generation and Phenotyping Organoid and Assembloid}<smiles>C1CCCCCC1</smiles>

Hazel Rogers

\section{ABSTRACT}

This protocol describes the derivation of organoid models from primary tumour tissue. It has been developed by the organoid derivation team within the Cellular Generation and Phenotyping Group at the Wellcome Sanger Institute. We have used the process to derive organoids from colon, pancreas and oesophageal tumours. The team has extensive experience in organoid derivation and have successfully banked over 100 models.

\section{GUIDELINES}

\section{General Information and tips}

- The tissue samples we process are transported from clinical sites in Advanced DMEM-F12 containing primocin antibiotic (final concentration $100 \mathrm{ug} / \mathrm{ml}$ ). Sampes are shipped chilled at $8^{\circ} 4{ }^{\circ} \mathrm{C}$

- We use $5 \mathrm{ml}$ Eppendorf tubes to help with sterility. However, if you do not have access to these tubes any alternative sterile tubes of appropriate volume can be used.

- We have experience of deriving organoid models from colon, oesophagus and pancreatic tumour tissue.

- We recommend using glass rather than plastic petri dishes for tissue dissection as tissue can get stuck in grooves cut into the plastic dish.

- Plate digested cells as close together as possible.

- Be very cautious at initial passages after derivation. Organoids can grow well for a few passages and then significantly drop off. We generally keep organoids in the same number of wells or reduce the area plated in if growth is slow or some cellular material has died.

- Not all derivations will be successful. Listed below are some common reasons we see for failure. 
Keywords: Organoid, Cancer, Derivation

\begin{tabular}{|c|c|c|}
\hline Reason & How do you know? & What does it look like? \\
\hline Lack of cells & $\begin{array}{l}\text { Insufficient starting } \\
\text { material. No/minimal } \\
\text { organoid formation } \\
\text { seen. }\end{array}$ & \\
\hline $\begin{array}{l}\text { No organoid } \\
\text { formation }\end{array}$ & $\begin{array}{l}\text { Viable cells present but } \\
\text { do not form organoids. }\end{array}$ & \\
\hline $\begin{array}{l}\text { Unable to } \\
\text { propagate }\end{array}$ & $\begin{array}{l}\text { Organoids form but } \\
\text { unable to expand. }\end{array}$ & \\
\hline $\begin{array}{l}\text { Growth has } \\
\text { dropped off }\end{array}$ & $\begin{array}{l}\text { Organoids were present } \\
\text { and expanding but have } \\
\text { since stopped reforming. }\end{array}$ & \\
\hline $\begin{array}{l}\text { Bacterial } \\
\text { contamination }\end{array}$ & $\begin{array}{l}\text { Media turns very yellow } \\
\text { and probably also } \\
\text { cloudy. Small bacteria } \\
\text { can be seen under high } \\
\text { magnification. }\end{array}$ & \\
\hline $\begin{array}{l}\text { Fungal } \\
\text { contamination }\end{array}$ & $\begin{array}{l}\text { May manifest as very } \\
\text { round, bright yellow } \\
\text { dots within BME2 } \\
\text { droplets or white } \\
\text { colonies on top. } \\
\text { Media may turn yellow } \\
\text { but can remain clear. }\end{array}$ & \\
\hline $\begin{array}{l}\text { Mycoplasma } \\
\text { contamination }\end{array}$ & $\begin{array}{l}\text { Cannot be detected } \\
\text { visually although } \\
\text { organoid growth may be } \\
\text { affected. } \\
\text { Repeatedly test positive } \\
\text { for mycoplasma. }\end{array}$ & - \\
\hline $\begin{array}{l}\text { Fibroblast } \\
\text { contamination }\end{array}$ & $\begin{array}{l}\text { Excessive fibroblast } \\
\text { outgrowth takes over } \\
\text { the culture. }\end{array}$ & \\
\hline
\end{tabular}

\section{Trouble Shooting}


BME2 is setting too quickly whilst plating.

Cells plated too densely resulting in BME breaking up.

One well is contaminated but rest of plate looks normal.

Culture is taken over by fibroblasts.
Try keeping your solution in a cooling rack whilst plating.

Harvest cells, BME2 and media in a tube. Pipette to break up BME2. Spin, then aspirate supernatant. If a lot of BME2 is left (grey haze above pellet) re-suspend in ice cold PBS, then repeat spin. If this does not work, re-suspend in TrypLE and incubate at $37^{\circ} \mathrm{C}$ for a few minutes before spinning. Re-suspend cell pellet in appropriate amount of BME2 and re-plate.

Aspirate media from contaminated well. Add $2 \mathrm{ml}$ chlorohexidine gluconate and leave for $30 \mathrm{~min}$. Aspirate entire contents of well and wash out with PBS. Keep an eye on remaining wells for the next few days.

Use a P1000 pipette to harvest organoids and media in a tube and wash wells with PBS. Fibroblasts tend to attach to the surface of the culture plate so should be left behind when the organoids are harvested. Spin then aspirate supernatant. Re-suspend in TrypLE and continue with passaging protocol. 


\section{MATERIALS}

MATERIALS

88 Falcon $15 \mathrm{~mL}$ Polystyrene Conical Tube Fisher Scientific Catalog \#352095

88 Penicillin Streptomycin Invitrogen - Thermo Fisher Catalog \#15140 122

88 DPBS no calcium no magnesium Thermo Fisher Scientific Catalog \#14190144

88 Collagenase, Type II, powder Thermo Fisher Catalog \#17101015

Cultrex® Reduced Growth Factor Basement Membrane Matrix Type 2 (BME

88

2) Trevigen Catalog \#3533-010-02

88 Falcon 50mL Conical Centrifuge Tubes Fisher Scientific Catalog \#14-432-2

Costar 6-well Clear TC-treated Multiple Well Plates Bulk Packed

Sterile Corning Catalog \#3506

88 Eppendorf Tubes $5.0 \mathrm{ml}$ Eppendorf Catalog \#0030122321

Anumbra Glass Petri Dish $100 \times 15 \mathrm{~mm}$ Scientific Laboratory Supplies

Ltd Catalog \#PET1008

88 Surgical Scalpel Blade No. 21 Swann Morton Catalog \#0507

$\$ 8$ Cell Strainers $100 \mu \mathrm{m}$ pore size VWR international Ltd Catalog \#732-2759

88 Pestle for Cell Strainer Sigma - Aldrich Catalog \#Z742105

88 Primocin InvivoGen Catalog \#ant-pm-1

88 Y-27632 dihydrochloride Sigma - Aldrich Catalog \#Y0503

\section{Equipment}

- Sterile cell culture hood

- Centrifuge

- $1000 \mu$ and $200 \mu$ l pipettes and tips

- Pipetteboy

- Stripettes

- $37^{\circ} \mathrm{C}$ waterbath

- $37^{\circ} \mathrm{C}$ humidified incubator $\left(5 \% \mathrm{CO}_{2}\right)$

- Light microscope

- Tube rotator 
Note

For full safety information refer to individual COSHH and MSDS forms

- Primocin can cause possible respiratory and skin sensitisation.

- Penicillin Streptomycin can cause possible respiratory and skin sensitisation. May also damage fertility or the unborn child.

- Rock inhibitor (Y-27632) is harmful if swallowed, inhaled or splashed on skin.

- Organoids derived from primary samples may contain uncharacterised adventitious agents, including blood-borne viruses.

\section{BEFORE START INSTRUCTIONS}

- Thaw BME2 aliquot overnight at $8^{\circ} 4^{\circ} \mathrm{C}$ and dilute 4:1 with appropriate organoid media (tissue specific) to make an $80 \%$ stock

- Ensure cell culture plates have been stored overnight in $8^{\circ} 37^{\circ} \mathrm{C}$ incubator

- Pre-warm organoid culture media to room temperature

- Prepare $100 \mathrm{mg} / \mathrm{ml}$ collagenase stock. Re-suspend $\triangle 1 \mathrm{~g}$ collagenase II in I $10 \mathrm{~mL}$ PBS. Aliquots can be stored at $8^{\circ}-20{ }^{\circ} \mathrm{C}$ for up to one year.

- Prepare digestion buffer:

\begin{tabular}{|l|l|l|}
\hline Reagent & Stock Concentration & Volume \\
\hline Organoid Media & - & $9.5 \mathrm{ml}$ \\
\hline Collagenase & $100 \mathrm{mg} / \mathrm{ml}$ & $0.5 \mathrm{ml}$ \\
\hline Primocin & $50 \mathrm{mg} / \mathrm{ml}$ & $0.02 \mathrm{ml}$ \\
\hline Penicillin Streptomycin & $100 \mathrm{X}$ & $0.1 \mathrm{ml}$ \\
\hline Rock inhibitor (Y-27632) (10 mM) & $10 \mathrm{mM}$ & $0.01 \mathrm{ml}$ \\
\hline
\end{tabular}




\section{Process Diagram}

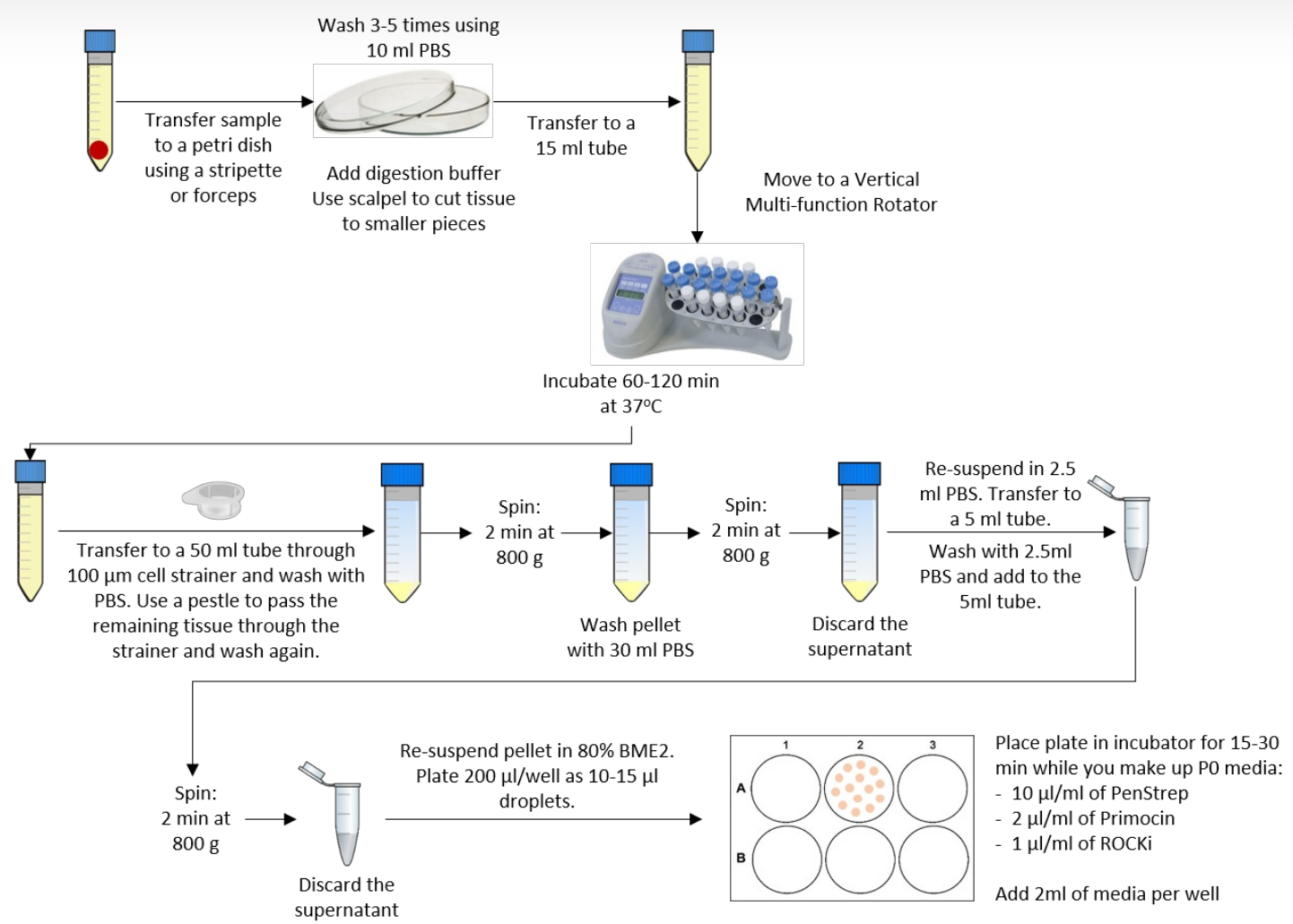

\section{Protocol}

2 Pour or pipette tissue, and media sample has been transported in, into a glass petri dish.

\section{Safety information}

If tissue has unknown infection status, only open the container the sample has been transported in within a microbiological safety cabinet.

Note

We recommend using glass rather than plastic petri dishes as tissue can get stuck in grooves cut into the plastic dish whilst cutting up the sample. 
3 Aspirate as much media as possible. Add $\triangle 10 \mathrm{~mL}$ PBS to wash the tissue sample. Aspirate PBS and repeat wash at least two more times (we perform 3 washes for pancreas and oesophagus and 5 washes for colon).

Note

After last wash make sure to aspirate as much PBS as possible to avoid diluting the digestion buffer.

Note

If tissue is breaking up, making aspiration difficult without losing the sample, transfer tissue and media back to the $\triangle 15 \mathrm{~mL}$ tube and centrifuge ( $\because 800 \times \mathrm{g}^{2}$ min). Asiprate supernatant and re-suspend in PBS to wash. Repeat these steps for appropriate number of washes.

4 Add \& $10 \mathrm{~mL}$ digestion buffer. Using a scalpel, cut sample into small pieces of approximately 1$2 \mathrm{~mm}$ in diameter. 


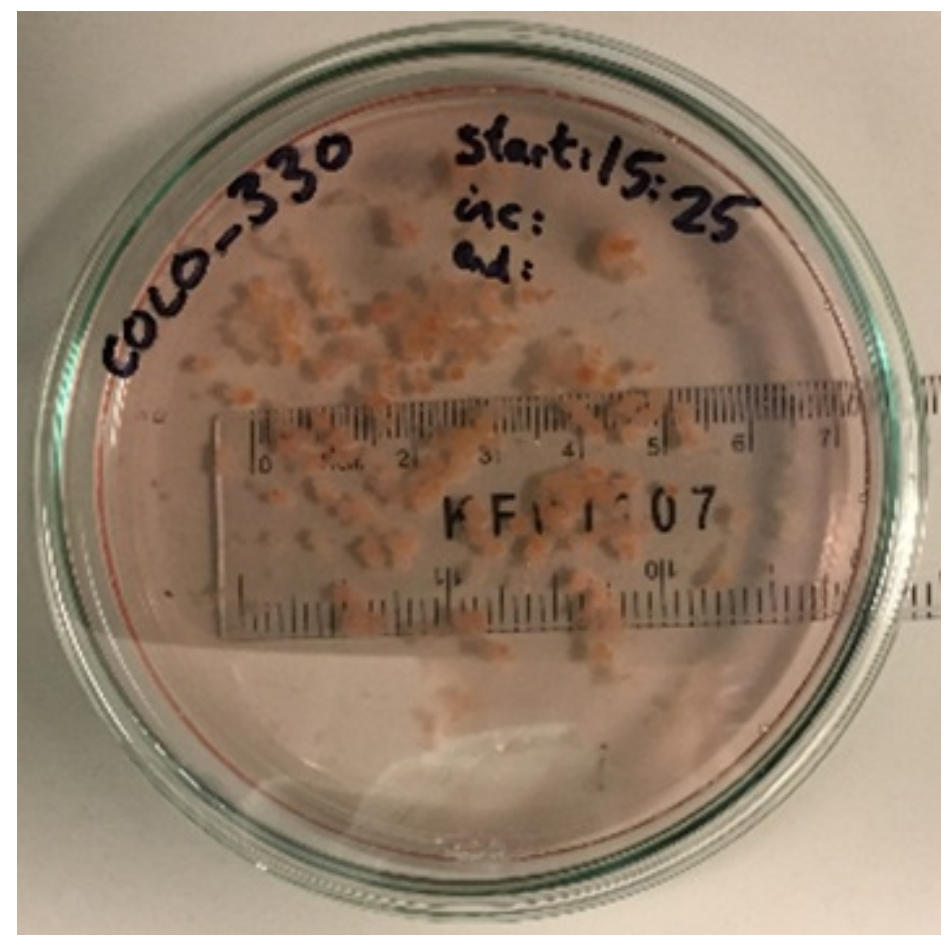

Tissue cut into small pieces

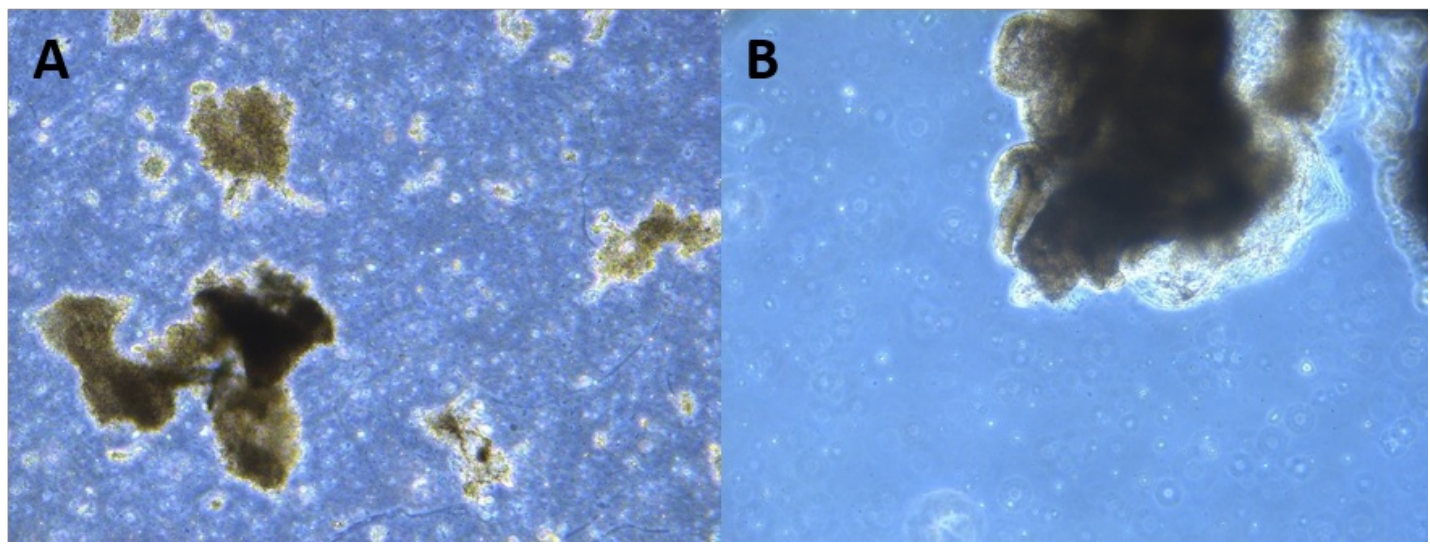

Examples of tissue samples with high (A) and low (B) celullarity (post cutting with a scalpel)

5 Transfer tissue and digestion buffer to a $\Delta 15 \mathrm{~mL}$ tube. Place sample in a tube rotator and incubate at $8^{\circ} 37^{\circ} \mathrm{C}$ for $60-120$ minutes.

6 Following incubation, assess tissue fragments under a microscope to confirm sufficient digestion. The sample should look cloudy to the eye and appear as single cells or small clumps under a 
microscope.

7 Transfer digested sample to a $\triangle 50 \mathrm{~mL}$ tube through a $100 \mu \mathrm{m}$ cell strainer. Use a pestle to pass any remaining tissue through the strainer. Wash the $\triangle 15 \mathrm{~mL}$ tube with $\mathbb{1} 10 \mathrm{~mL}$ PBS and add to the $\triangle 50 \mathrm{~mL}$ tube through the cell strainer. Repeat the wash step.

$8 \quad$ Centrifuge at $\because 800 \times \mathrm{g}$ for 2 minutes.

9 Aspirate supernatant and re-suspend pellet in $\triangle 30 \mathrm{~mL}$ PBS. Repeat spin at $\because 800 \times \mathrm{g}$ for 2 minutes.

Note

When aspirating, you do not need to worry about getting too close to the pellet at this stage.

10 Aspirate supernatant and re-suspend pellet in $\triangle 2.5 \mathrm{~mL}$ PBS. Transfer to a $\triangle 5 \mathrm{~mL}$ tube (or I $15 \mathrm{~mL}$ tube). Wash \& $50 \mathrm{~mL}$ tube with another \& $2.5 \mathrm{~mL}$ PBS and transfer to I $5 \mathrm{~mL}$ tube. Repeat spin at $\because 800 \times \mathrm{g}$ for 2 minutes.

Note

Transferring to a smaller volume tube helps with re-suspension in a small volume of BME2 in the next step.

11 Aspirate as much supernatant as possible. Re-suspend cell pellet in appropriate amount $80 \%$ BME2 ( $\triangle 200 \mu \mathrm{L}$ per well of a 6 well plate). 
BME2 must be dispensed as quickly as possible as it will begin to set at room temperature. A cool block could be used to help keep the temperature down while plating.

Note

Volume of BME2 to re-suspend in must be determined from size of cell pellet. Aim to plate cells as close together as possible. If unsure re-suspend in a small volume. Pipette one or two $\triangle 15 \mu \mathrm{L}-\triangle 20 \mu \mathrm{L}$ droplets and check under the microscope. If too dense increase BME2 volume.

12 Using a P200 pipette, dispense organoid/BME2 suspension as small $\triangle 15 \mu \mathrm{L}-\Delta 20 \mu \mathrm{L}$ droplets into a 6 well plate (seed $\triangle 200 \mu \mathrm{L}$ per well).

13 Place in a $37^{\circ} \mathrm{C}$ incubator $\left(5 \% \mathrm{CO}_{2}\right)$ for $15-30$ minutes to allow BME2 to set.

14 Prepare media containing antibiotics and Y-27632 (rock inhibitor). Add volumes below per ml of appropriate culture media:

- $\ 2 \mu \mathrm{L}$ primocin

- I $10 \mu \mathrm{L}$ penicillin streptomycin

- $\triangle 1 \mu \mathrm{L}$ Y-27632

15 Add $\triangle 2 \mathrm{~mL}$ of appropriate prepared media per well of a 6 well plate.

16 Return to incubator. Media change twice a week until ready to passage. Keep in media containing 
antibiotics and $\mathrm{Y}-27632$ until first passage.

\section{Full Process Video}

